\title{
Feasibility of Applying Clean Development Mechanism and GHGs Emission Reductions in the Gold Mining Industry: A Case of Thailand
}

\author{
Suthirat KITTIPONGVISES* \\ Environmental Research Institute, Center of Excellence on Hazardous Substance Management, \\ Chulalongkorn University, Bangkok 10330, Thailand
}

\begin{abstract}
There is presently overwhelming scientific consensus that global climate change is indeed occurring, and that human activities are the primary driver. An increasingly resource and carbon constrained world will continue to pose formidable challenges to major industries, including mining. Understanding the implications of climate change mitigation for the mining industry, however, remains limited. This paper presents the results of a feasibility study on the implementation of a clean development mechanism and greenhouse gases (GHGs) emission reductions in the gold mining industry. It draws upon and extends the analysis of a case study conducted on gold mining operations in Thailand. The results from the case study indicated that total GHGs emissions by company A were approximately 36,886 tons carbon dioxide equivalents $\left(\mathrm{tCO}_{2} \mathrm{e}\right)$ per annual gold production capacity that meet the eligibility criteria for small-scaled clean development mechanism (CDM) projects. The electrostatic separation process was found to release the lowest amount of GHGs, whereas comminution (i.e. crushing and grinding) generated the highest GHGs emissions. By scope, the emission from purchased electricity (scope 2) is the most significant source. Opportunities for CDM projects implementation in the gold mining sector can be found in employing energy efficiency measures. Through innovation, some technical efficiency and technological development in gold processing (i.e. high pressure grinding rolls (HPGR), vertical roller mills (VRM), gravity pre-concentration and microwave heating technologies) that have the potential to reduce energy use and also lower carbon footprint of the gold mining were further discussed. The evidence reviews found that HPGR and VRM abatement technologies have shown energy and climate benefits as electricity savings and $\mathrm{CO}_{2}$ reduction of about 8-25.93 $\mathrm{kWh} /$ ton ore processed and $1.8-26.66 \mathrm{kgCO}_{2} /$ ton ore processed, respectively. Implications for further research and practice were finally raised.
\end{abstract}

Keywords - CDM; GHGs emission reductions; gold mining industry; Thailand

\section{INTRODUCTION}

Global climate change poses a fundamental threat to sustainable development and human security in the $21^{\text {st }}$ century. One major cause is anthropogenic emissions that cause a rapid increase in the atmospheric concentrations of greenhouse gases (GHGs), resulting in negative impacts on both environmental and socio-economic development [1]. From a mitigation perspective, there have been several efforts made by international partnerships to reduce or remove collective GHGs emissions under the Kyoto Protocol, including emission trading (ET), joint implementation (JI) and the clean development mechanism (CDM). Under emission trading, a country with more emission rights than it anticipates using can trade this surplus to countries that would otherwise exceed their permitted amounts. As noted, this trading of emissions is limited only to Annex I or

\footnotetext{
* Corresponding author.

E-mail address: suthirat.k@chula.ac.th
}

(C)2015 Suthirat Kittipongvises. This is an open access article licensed under the Creative Commons Attribution License

(http://creativecommons.org/licenses/by/4.0), in the manner agreed with De Gruyter Open. 
industrialized countries. Under joint implementation and the clean development mechanism, an investor invests in an emission-reduction project aboard, emissions reductions are verified and in exchange for the investment, the project investor receives carbon credits (e.g., emissions reduction units for JI and certified emission reductions for CDM). Thus, the project can emit the total of its allowance under the protocol [2], [3]. In this context, the difference between JI and CDM is that the host country of the project is a developed country for JI and a developing country for CDM. Overview of the CDM's current status in Thailand is further illustrated.

An industry sector is an important source of emissions from both energy uses and industrial processes [4]. By way of explanation, industry-related GHG emissions have continued to increase and are higher than emissions from other end-use sectors. Globally, emissions are dominated by a developing region, in this case Asia, which was the region with faster GHG emissions growth between 2005 and 2010 [5]. In Thailand [6], mineral production (2A mineral products) is the largest source of GHG emissions in industrial processes (accounting for 97.9\% in 2000). The International Council of Mining and Metals has recognized the particular impacts of GHGs as the most concerning environmental issue, without a doubt, to face the mining industry [7]. By combining these insights, mining management is definitely needed to reduce point sources of pollution, specifically GHG emissions that contribute to global climate change. However, implementation of mitigation activities by the mining industry has lagged behind its perceived potential. The purpose of this study was to explore the feasibility of applying CDM and GHG emission reduction in the gold mining industry in Thailand. Reviews of the literature on current status of CDM projects in Thailand, gold mineral resources of Thailand and the emissions of GHGs from industrial production process are firstly provided.

\subsection{Current Situation of CDM in Thailand}

CDM was principally created with the dual goals of achieving GHG emission reduction targets and promoting sustainable development in host countries [2]. As a non-Annex I member country, the Thailand Greenhouse Gas Management Organization (TGO) was established in 2007 to be responsible for sustainable development in Thailand through CDM activities. As of October 2013, Thailand has implemented about $221 \mathrm{CDM}$ projects that have been issued a Letter of Approval (LoA) by the TGO, with expected average annual carbon credits of about twelve million tons carbon dioxide equivalent $\left(\mathrm{tCO}_{2} \mathrm{e}\right)$. Among these projects, about 148 projects were registered by the CDM Executive Board (CDM EB) and 35 of these have received carbon credits issued by CDM EB [8]. Most registered CDM projects in Thailand are implemented through either biogas or biomass energy generation, as depicted in Fig. 1.

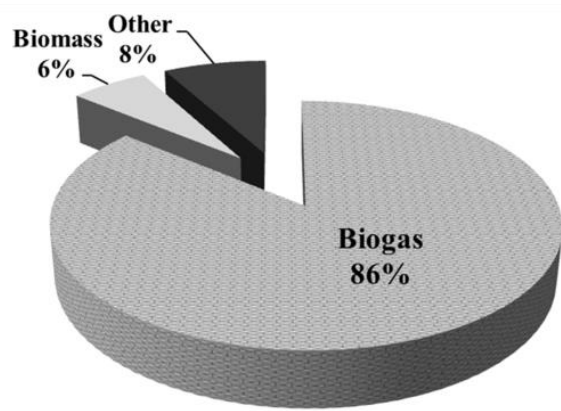

Fig. 1. Number of CDM projects registered in Thailand in 2013. 


\subsection{Eligible CDM Project Activities}

CDM project activities must result in reducing GHGs that are real and measurable and would not have occurred in the absence of the proposed project activities. The eligible criteria for CDM projects are: (i) CDM project activities must be developed only through voluntary action, (ii) CDM projects must promote sustainable development in host countries, (iii) CDM projects are subject to stakeholder consultations and initial assessment of environmental impacts created by the project activities, (iv) CDM project activities must meet the "additionality" requirements, in terms of finance, technology and environmental aspects, and (v) all the processes of CDM projects must be transparent, efficient and accountable, under independent auditing and verification. Possible types of CDM project activities depend on the sectoral scope, as summarized in Table 1.

TABle 1. Possible TyPes of CDM PRoJect ACtivities [9]

\begin{tabular}{|c|c|c|}
\hline & Scope & Project activities \\
\hline \multirow{2}{*}{1} & \multirow{2}{*}{ Energy Industries } & Coal switching to natural gas \\
\hline & & Solar PV, wind power, hydro, biomass, geothermal, etc. \\
\hline 2 & Energy Distribution & Electric power transmission and distribution \\
\hline 3 & Energy Demand & High efficiency energy equipment \\
\hline 4 & Manufacturing Industries & $\begin{array}{l}\text { Waste heat recovery, clean coal technology, high efficiency energy } \\
\text { equipment }\end{array}$ \\
\hline 5 & Chemical Industries & Industrial gas abatement \\
\hline 6 & Construction & Metal substitution, energy saving \\
\hline 7 & Transport & Improved the energy efficiency of vehicles \\
\hline 8 & Mining/Mineral Production & $\begin{array}{l}\text { Fuel substitution (i.e., clean coal technology), improved efficiency of } \\
\text { process }\end{array}$ \\
\hline 9 & Metal Production & $\begin{array}{l}\text { Fuel substitution (i.e., clean coal technology), improved efficiency of } \\
\text { process }\end{array}$ \\
\hline 10 & Fuel Substitution & \\
\hline 11 & $\begin{array}{l}\text { Fugitive Emissions from } \\
\text { Combustion }\end{array}$ & Gas recovery and utilization \\
\hline 12 & Solvent Use & Material substitution \\
\hline 13 & Waste Handling and Disposal & $\begin{array}{l}\text { Waste-to-energy systems (i.e., wastewater treatment and landfill } \\
\text { gas recovery) }\end{array}$ \\
\hline 14 & Afforestation & Afforestation and reforestation \\
\hline 15 & Agriculture & Avoidance of methane emission from biomass decay \\
\hline
\end{tabular}

\subsection{Mineral and Gold Resources of Thailand}

The mining and quarrying sector of Thailand was important in the country's economy [10]. Acknowledging this fact, the mineral royalty revenues of Thailand in the fiscal year of 2013 was approximately 3,089.2 million baht (91.70 million USD). In 2013, limestone, lignite, gold, gypsum, and silver were the five most valuable minerals produced in Thailand (Fig. 2). Of this, gold royalty revenues of Thailand were approximately 597.5 million baht (17.74 million USD) in 2013 [11]. 


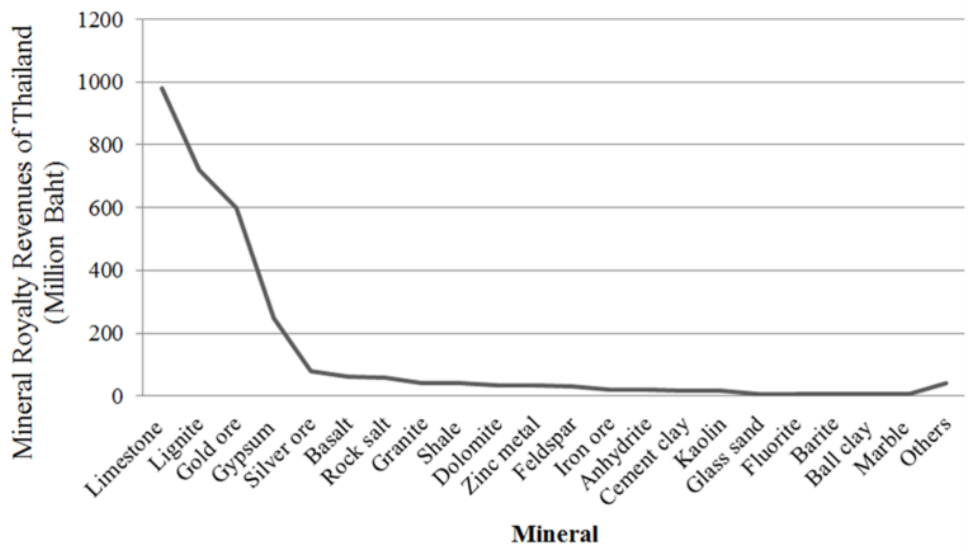

Fig. 2. Mineral royalty revenues of Thailand in 2013.

\subsection{GHGs Emissions From Industrial Production Process}

As a part of its Second National Communication to the UN Framework Convention on Climate Change [12], in 2000, Thailand's net $\mathrm{CO}_{2}$ emissions were 229.08 $\mathrm{Tg} \mathrm{CO}_{2}$ eq. The energy sector was the largest contributor at about $69.6 \%$, followed by the agricultural sector at $22.6 \%$. The remaining proportion was shared among industry and waste management. In terms of the industrial sector, most of the emissions were from mineral production processes, as illustrated in Fig. 3.

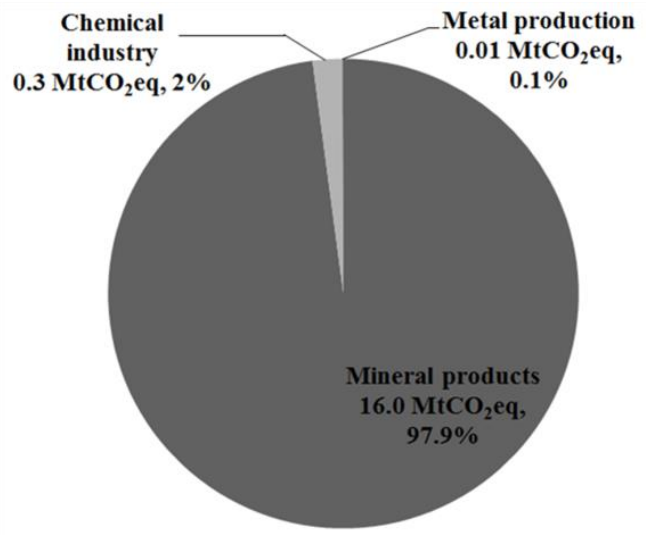

Fig. 3. Thailand's GHG emissions in 2000, by the industrial sector.

\section{MATERIALS AND METHODS}

\subsection{Case Study}

This paper extends the analysis of a case study that examined gold mining operations in Thailand. Company A, located in the northern region of Thailand approximately 280 kilometres north of Bangkok was selected as a key case. 


\subsection{Method for GHGs Quantification in the Industry Sector}

Generally, there are several methods that can be used to quantify GHG emissions from industrial sources. The appropriate calculation method to use mainly depends on available activity data, suitable emission factors (EF) and also assumptions made. According to [13], [14], the GHG emissions generated by an organization can be classified into three scopes (Table 2):

\section{TABLE 2. THREE-SCOPES OF GHGS EMISSIONS}

\begin{tabular}{ll}
\hline $\begin{array}{l}\text { Scope 1 } \\
\text { (Direct } \\
\text { emissions) }\end{array}$ & $\begin{array}{l}\text { Emissions are direct GHG emissions from sources that are owned by the entity. For instance, } \\
\text { emissions from fossil fuels burned on-site (stationary emission), emissions from entity-owned } \\
\text { vehicles (mobile emission), etc. }\end{array}$ \\
\hline $\begin{array}{l}\text { Scope 2 } \\
\text { (Indirect } \\
\text { emissions) }\end{array}$ & $\begin{array}{l}\text { Emissions are indirect GHG emissions resulting from purchased electricity, heat, or steam } \\
\text { consumed but not directly generated by the entity. }\end{array}$ \\
\hline $\begin{array}{l}\text { Scope 3 } \\
\text { (Indirect } \\
\text { emissions) }\end{array}$ & $\begin{array}{l}\text { Emissions include indirect GHG emissions from sources not owned or directly controlled by the } \\
\text { entity but related to the entity's activities. For instance, employee commuting contracted solid } \\
\text { waste disposal and wastewater treatment, etc. }\end{array}$ \\
\hline
\end{tabular}

Note: Only scope 1 and 2 are defined for GHGs accounting in this study.

Further to this, regarding to the guidance manual for estimating GHG emissions [14], [15], the calculation of GHGs from the potential sources can be done by the following approach:

\section{(i) Direct emissions from mobile combustion source}

Equation 1 can be used to estimate the amount of direct emissions related to on-site mobile combustion activities.

$$
\text { Emissions }\left(\mathrm{tCO}_{2 e}\right)=\text { Quantity of fuel combusted } \text { fab } \cdot E F
$$

where a - fuel type; $b$ - vehicle type

(ii) Direct emissions from non-combustion activities (e.g., industrial processes)

In the mining industry, these emissions can be quantified using the mass of explosives and appropriate EF of the explosive type. For an explosive mixture, as ANFO (ammonium nitrate/fuel oil), $\mathrm{a} \mathrm{CO}_{2} \mathrm{EF}$ of 0.189 ton of $\mathrm{CO}_{2}$ per ton of ANFO can be used to assess the GHG emission [16].

\section{(iii) Indirect emissions from electricity purchased}

Equation 2 can be used to estimate the amount of indirect emissions related to the consumption of purchased electricity from the grid.

Emissions $\left(\mathrm{CCO}_{2 e}\right)=$ Quantity of electricity purchased from the grid $(\mathrm{kWh}) \cdot \mathrm{EF}$

All EFs used in this study derived from Thailand Greenhouse Gas Management Organization (TGO). These data were calculated based on a one-year inventory period. 


\section{RESULTS AND DISCUSSION}

\subsection{Gold Mine ore Processing of the Company A}

Gold company A is a conventional open-pit mining enterprise. Gold at the mine, on this basis, is extracted from an open pit (C-H pit) that uses a stripping process to uncover the reef layer-bylayer. The main rock types at the $\mathrm{C}-\mathrm{H}$ pit are classified as andesitic lithic breccia, plagioclasepyroxene-porphyritic andesite and crystal-lithic breccia units, which are overlain by laterite and alluvial deposit. Annual gold production is roughly 2,500,000 tons per annum of ore. Altogether, the process of producing gold can be divided into 5-6 main phases (see Fig. 4):

Site development: After finding the orebody (exploration), there are several activities that will help facilitate the development of the mining site, including preparing the site for production by mine shaft sinking or pit excavation, constructing facilities and building mine access roads.

Drilling and blasting: Drilling and blasting are usually necessary to break the orebody, prior to mining. Gold ore is then mined using large diesel hydraulic excavators, loading a combination of 20- and 35-ton haul trucks.

Digging up and transport: After breaking the orebody, the broken material from mining face is consequently transported to the concentrator or processing plant using haul trucks.

Crushing and grinding: Crushing and grinding are done to break the ore up into particles as small as the grain size of the desired mineral component. This is undertaken by a combination of multi-stage crushing and milling circuits with associated classification and screening processes. Company A's processing plant consists of a single stage crusher followed by a two-stage grinding circuit comprising a semi-autogenous grinding (SAG mill) and ball mill. Orebody is fed into the SAG mill along with water and steel balls. The grinding process reduces the ore particles to slurry that is fine enough ( $<75$ micrometers) to pass through the primary and secondary cyclone.

Magnetic separation: After crushing and grinding, the slurry then moves through a series of carbon adsorption tanks. Gold is recovered by gravity force using a centrifugal concentrator followed by an intensive leach reactor where a sodium solution is added. Company A, the leach ore circuit comprises 12 tanks, 11 of which contain carbon to recover gold in solution. The tank provides sufficient retention time (12-20 hours) to allow the gold to be dissolved by cyanide. Accordingly, carbon is fed into the circuit in the opposite direction to the slurry flow, moving from the last tank to the first. Most of the precious metals have then been removed by the time slurry reaches the final tank. Pregnant eluate (the washed solution) is then passed through a series of electro-wining cells. The barren slurry, called tailing, is either pumped to the Tailings Storage Facility (TSF) or treated to neutralize or recovery the cyanide.

Electrostatic separation: After magnetic separation, pregnant eluate solution is passed through electrowining cells, containing a set of cathodes (negative electrodes) in the form of stainless steel plates. Gold attaches itself to the stainless steel cathodes. The cathodes are then removed and rinsed to yield a muddy sludge before reuse. Muddy sludge is then dried and put into the furnace at high temperature and, after several hours (16-20 hours), the molten material is poured into a cascade of molds to produce gold bars called "doré bars". 


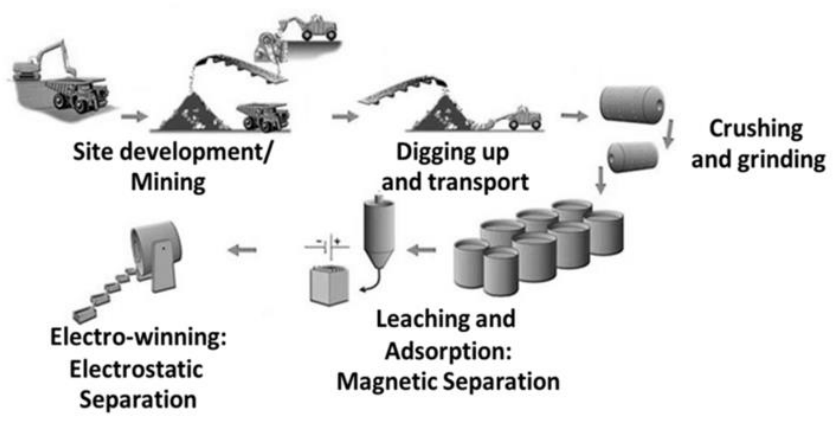

Fig. 4. Flow diagram of gold ore processing (Modified from [17]).

\subsection{GHG Emissions of Gold Production}

\section{Identification of emission sources.}

Theoretically, GHG emissions can be calculated as the quantity of substance going in and out of an entire facility and process of gold production per annum (Fig. 5). As noted, scope 1 (see Table 2) covers direct GHG emissions from sources owned by the Company A (e.g. the amount of diesel fuel consumed and the amount of chemical used in gold production process). Scope 2 covers indirect emissions of GHGs from the purchase of electricity from the grid.

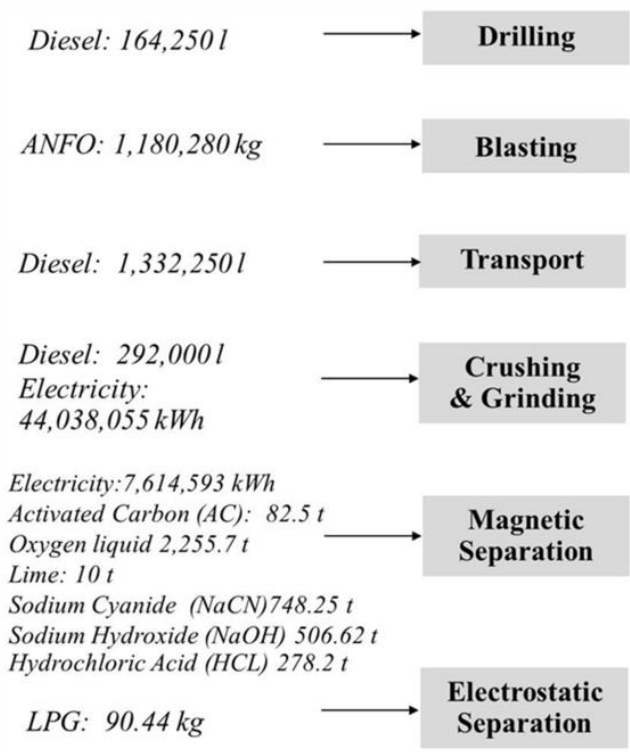

Fig. 5. Potential sources of emissions in each process of the company A [18].

\section{Quantification of GHGs emission.}

EFs ( $\mathrm{kgCO}_{2}$ eq per unit) issued by [16], [19], [20] were used to estimate emissions of GHGs by Equations 1 and 2. As a result, total GHG emissions from both direct and indirect sources were approximately $36,886 \mathrm{tCO}_{2} \mathrm{e}$ per annual gold production capacity. Comminution (i.e. crushing and 
grinding) process releases the highest $\mathrm{GHG}$ emissions $\left(26,387 \mathrm{tCO}_{2} \mathrm{e}\right.$ per annual production capacity), whereas the electrostatic separation process generates the lowest emissions $\left(281 \mathrm{tCO}_{2} \mathrm{e}\right.$ per annual gold production capacity) (Table 3). These findings are in line with a study conducted by [21] found that crushing and grinding processes make the largest contribution (about $47 \%$ ) to the GHGs emissions for the copper mine production.

TABle 3. GHGs EMISSIONS OF Gold PRODUCTION PROCESS OF THE COMPANY A

\begin{tabular}{|c|c|c|c|c|c|c|c|}
\hline \multirow[b]{2}{*}{$\begin{array}{l}\text { Production } \\
\text { processes }\end{array}$} & \multicolumn{3}{|c|}{ Scope 1: Direct emissions } & \multicolumn{3}{|c|}{ Scope 2: Indirect emissions } & \multirow{2}{*}{$\begin{array}{l}\mathrm{Net}^{\mathrm{CO}_{2 \mathrm{e}}} \\
\text { emission } \\
\text { (direct } \\
\text { and } \\
\text { indirect; } \\
\text { kgCO}_{2 \mathrm{e}} \text { ) }\end{array}$} \\
\hline & $\begin{array}{l}\text { Energy and } \\
\text { chemical used } \\
\text { (unit) }\end{array}$ & $\begin{array}{l}\mathrm{EF} \\
\text { (kgCO } \mathrm{CO}_{\mathrm{eq}} \\
\text { per unit) }\end{array}$ & $\begin{array}{l}\mathrm{CO}_{2} \\
\text { emission } \\
\left(\mathrm{kgCO}_{2 \mathrm{e}}\right)\end{array}$ & $\begin{array}{l}\text { Electricity } \\
\text { consumed }\end{array}$ & $\begin{array}{l}\text { EF } \\
\left(\mathrm{kgCO}_{2 \mathrm{eq}}\right. \\
\text { per unit) }\end{array}$ & $\begin{array}{l}\mathrm{CO}_{2 \mathrm{e}} \\
\text { emission } \\
\left(\mathrm{kgCO}_{2 \mathrm{e}}\right)\end{array}$ & \\
\hline Drilling & $\begin{array}{l}\text { Diesel: } 164,250 \\
\text { (1) }\end{array}$ & 2.7446 & 450,800 & - & - & - & 450,800 \\
\hline Blasting & ANFO: $1,180(\mathrm{t})$ & 0.189 & 223,073 & - & - & - & 223,073 \\
\hline Transport & $\begin{array}{l}\text { Diesel: } \\
1,332,250(1)\end{array}$ & 2.7446 & $3,656,493$ & - & - & - & $3,656,493$ \\
\hline $\begin{array}{l}\text { Crushing \& } \\
\text { grinding }\end{array}$ & $\begin{array}{l}\text { Diesel: } 292,000 \\
\text { (1) }\end{array}$ & 2.7446 & 801,423 & $\begin{array}{l}\text { Electricity: } \\
44,038,055 \\
(\mathrm{kWh})\end{array}$ & 0.581 & $25,586,109$ & $26,387,532$ \\
\hline \multirow{5}{*}{$\begin{array}{l}\text { Magnetic } \\
\text { separation }\end{array}$} & $\begin{array}{l}\text { AC: } 82.5(\mathrm{t}) \\
\text { Oxygen liquid: } \\
2,255,000(\mathrm{~kg})\end{array}$ & $\begin{array}{l}\text { N/A } \\
0.4690\end{array}$ & $\begin{array}{l}- \\
1,057,923\end{array}$ & \multirow{5}{*}{$\begin{array}{l}\text { Electricity: } \\
7,614,593 \\
(\mathrm{kWh})\end{array}$} & \multirow{5}{*}{0.581} & \multirow{5}{*}{$4,424,078$} & \multirow{5}{*}{$6,168,495$} \\
\hline & $\begin{array}{l}\text { Lime: } 10,000 \\
(\mathrm{~kg})\end{array}$ & 0.7820 & 7,820 & & & & \\
\hline & $\begin{array}{l}\mathrm{NaCN}: \\
74,825,000(\mathrm{~kg})\end{array}$ & N/A & - & & & & \\
\hline & $\mathrm{NaOH}:(k g)$ & 1.1148 & 564,779 & & & & \\
\hline & $\begin{array}{l}\text { HCL: } 2,782,000 \\
(\mathrm{~kg})\end{array}$ & 0.4094 & 113,895 & & & & \\
\hline $\begin{array}{l}\text { Electro- } \\
\text { static } \\
\text { separation }\end{array}$ & LPG: $90.44(\mathrm{~kg})$ & 3.1131 & 281 & - & - & - & 281 \\
\hline Total & & & $6,876,487$ & Total & & $30,010,187$ & $36,886,674$ \\
\hline
\end{tabular}

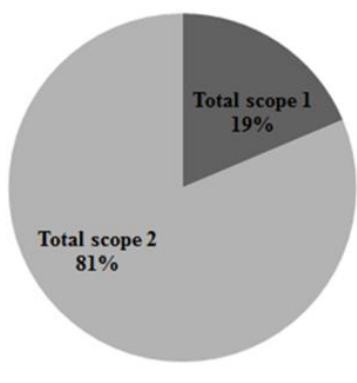

(a)

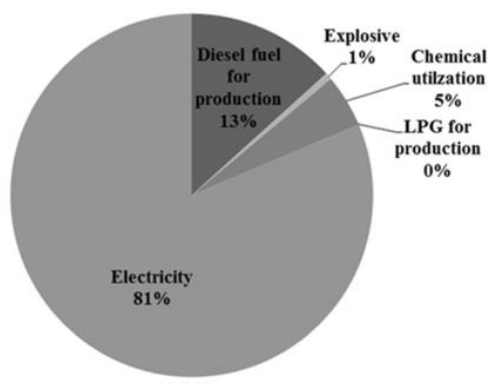

(b)

Fig. 6. GHG emissions by scope and main sources. 
Furthermore, the distribution of GHG emissions by scopes clearly indicates that the emissions from scope 2 are the most significant source (Fig. 6a). Other emissions from used explosives and materials production are very small compared to emissions from electricity (Fig. 6b). This result is consistent with previous studies [22]-[24] that the combustion of fossil fuels to generate electricity is the largest source of $\mathrm{CO}_{2}$ emissions. Of these, more than $50 \%$ of total electricity was used for crushing and grinding processes [25]. In comparison with other mines, [18] found that GHG emissions from lignite and limestone mining in Thailand were approximately 571,539 and $20,878 \mathrm{tCO}_{2} \mathrm{e}$ per annual production capacity, respectively.

\subsection{Feasibility of Applying CDM and GHG Reduction Technologies to the Gold Mining Industry}

Small-scale CDM projects, basically, include those which reduce less than $60,000 \mathrm{tCO}_{2} \mathrm{e}$ in emission reductions per year, renewable energy project activities with a maximum output capacity equivalent of up to 15 megawatts or energy efficiency improvement projects reducing energy consumption by up to 60 gigawatt hour (GWh) per year (both at supply and demand side) [26]. Therefore, it is possible for Company A to apply a small-scale CDM project, because total GHG emissions were about $36,886 \mathrm{tCO}_{2} \mathrm{e}$ per annual gold production capacity $\left(<60,000 \mathrm{tCO}_{2} \mathrm{e}\right)$. With the highest $\mathrm{CO}_{2}$ emissions, comminution and magnetic separation present a significant opportunity for the application of a CDM project in gold mining. GHG emissions are mainly associated with electricity use and chemical reactions during gold production. As a general concept, opportunities for CDM projects in the gold mining sector can be found in employing energy efficiency measures, fuel switching, generating electricity from renewable energy sources and improving the efficiency of the magnetic separation procedure. By way of illustration, [24] reported that small-scale CDM project involves switching fuel from coal to cleaner fuels and renewable energy. Currently, as part of the gold extraction process, geothermal power station was constructed to supplement the existing facilities with renewable energy. The project reduced GHG emissions, energy costs as it improved the reliability of the power supply [27].

To addressing environmental and climate change problems, there are a number of technological developments occurring in the mining and mineral processing that have shown the potential to minimize resource utilization, particularly, reduce their electricity consumption and carbon footprint [28]. US Department of Energy [29] also reported that the metals and mining industry in the US has the potential to reduce energy consumption by about $61 \%$ from current state to the best-estimated practical minimum energy consumption. Table 4 shows the potential energy savings for the various states of mining and mineral processing over their entire life cycle.

TAble 4. Potential Energy Savings For the Mining and Mineral Processing Life CyCle (MODIFIED FROM [29])

\begin{tabular}{lll}
\hline \multirow{2}{*}{ Stage } & \multicolumn{2}{c}{ Potential energy savings } \\
\cline { 2 - 3 } & MJ/t ore & $\%$ \\
\hline Drilling & 1.2 & 43 \\
Blasting & 6.7 & 59 \\
Loading and hauling & 45.7 & 52 \\
Crushing and grinding & 157.4 & 71 \\
\hline
\end{tabular}

It can be seen from Table 4 that the comminution (i.e. crushing and grinding) process offers the greatest opportunity for energy savings per ton of ore processed [21]. Some of the emerging technologies that could contribute to energy saving foe those processing stags are described below: 
High pressure grinding rolls (HPGR) technology

Electricity consumption in crushing and grinding processes of gold production, as noted earlier, made the greatest contribution to the GHG footprint. HPGR, a very efficient in terms of energy savings, presents the general idea that applying high pressure to a bed of particles may bring environmental gains regarding energy efficiency (60-80 percent) and gold recovery (70-80 percent) (Table 5) [30], [31]. This technology has been considered for metalliferous minerals, such as iron, copper and gold [32]. In gold mining, the applications of HPGR technology are: (i) replacing crushing and grinding stages, (ii) replacing AG/SAG grinding aiming at increased capacity and lower energy consumption.

\section{TABle 5. Percentage of Gold Recovery From CONVEntional COMMinution AND} HPGR [23]

\begin{tabular}{lllll}
\hline \multirow{2}{*}{$\begin{array}{l}\text { Particle size } \\
\text { P80 }(\boldsymbol{\mu} \mathbf{m})\end{array}$} & \multicolumn{2}{c}{ Conventional } & HPGR \\
\cline { 2 - 5 } & Residue $(\mathbf{g} / \mathbf{t})$ & Gold recovery $(\boldsymbol{\%})$ & Residue $(\mathbf{g} / \mathbf{t})$ & Gold recovery $(\boldsymbol{\%})$ \\
\hline 4000 & 0.10 & 79.0 & 0.22 & 57.9 \\
425 & 0.12 & 78.3 & 0.17 & 69.0 \\
325 & 0.11 & 2.1 & 0.13 & 73.1 \\
\hline
\end{tabular}

\section{Vertical roller mills (VRM) technology}

Vertical roller mills are an energy-efficient alternative to conventional grinding technology in the mining industry. Energy saving of about 6-7 kWh/t-raw materials are assumed through the installation of VRM technology [33]. On the greenhouse gas front, [34] reported that $\mathrm{CO}_{2}$ emissions can be reduced by 7.9 to $19 \mathrm{~kg} / \mathrm{t}$-cement capacity and 8.1 to $19.4 \mathrm{~kg} / \mathrm{t}$-cement capacity with the use of this technology in China and India, respectively.

\section{Gravity pre-concentration method}

Norgate \& Haque [22] argued that although gravity concentration is not a new technique, recent studies on development of equipment type (i.e., inline pressure jigs, the Knelson and Falcon centrifugal separators [35]) have been used for pre-concentration of gold ores for conventional carbon adsorption. The aim of this approach is to maximize the recovery of the liberation of the gold-bearing minerals at coarse particle sizes, thereby reducing energy requirements for communition and also increasing gold recovery.

\section{Microwave heating technology}

To improve the efficiency of conventional grinding which is the most energy-intensive step in gold processing, microwave heating technique can be used to induce thermal-stress cracking to decrease energy requirements of the grinding process. A study done by [36] found that over $95 \%$ ore extraction was achieved within 12 hours as against 22 hours for non-microwave samples. This technique could therefore lead to a decrease in the greenhouse footprint of gold ore mining [22].

Table 6 compares energy savings and $\mathrm{CO}_{2}$ emission reduction potential for each abatement technology, especially for the grinding process in the mining and mineral industry (i.e. cement production). Both HPGR and VRM have shown energy and climate benefits as electricity savings and $\mathrm{CO}_{2}$ reduction of about $8-25.93 \mathrm{kWh} /$ ton ore processed and $1.8-26.66 \mathrm{kgCO}_{2} /$ ton ore processed, respectively [37]-[39]. Whereas, use of gravity system in preparation of raw material 
made only a small contribution to the overall energy conservation and $\mathrm{CO}_{2}$ reduction, amounting to $2.64 \mathrm{kWh} /$ ton ore processed and $1.37 \mathrm{kgCO}_{2} /$ ton ore processed, respectively [37]. Eventually, due to limited number of studies available, these findings emphasize the need to focus on energy efficient technology as a low carbon development in the mining sector, especially gold mining.

TABLE 6. $\mathrm{CO}_{2}$ Reduction Potentials AND ENERGy SAVINGS IN THE GRINDING PROCESS

\begin{tabular}{llll}
\hline $\begin{array}{l}\text { Energy savings } \\
\text { measures }\end{array}$ & $\begin{array}{l}\text { Energy savings }(\mathbf{k W h} / \mathbf{t} \\
\text { ore processed*) }\end{array}$ & $\begin{array}{l}\mathbf{C O}_{2} \text { emission reduction (both } \\
\text { direct and indirect sources; } \\
\mathbf{k g C O}_{2} / \text { t ore processed*) }\end{array}$ & Reference \\
\hline HPGR technology & 16 & 8.30 & {$[37]$} \\
& 24.41 & 25.09 & {$[38]$} \\
VRM technology & $8-28$ & $1.8-6.3$ & {$[39]$} \\
Use of gravity system & 17 & 8.82 & {$[37]$} \\
for material preparation & 25.93 & 26.66 & {$[38]$} \\
*on clinker & & 1.37 & {$[37]$} \\
\hline
\end{tabular}

\section{CONCLUSIONS AND IMPLiCATIONS}

Reducing GHG emissions arising from human activities is central to achieving a low-carbon society and restricting average global temperature increases. To the extent possible, the mining industry is endeavoring to find opportunities to develop technologies to achieve the sustainability goals [40]. CDM is one of the flexibility mechanisms that offers emission reduction projects which generate carbon credit (or certified emission reduction units) that may be traded in emission trading schemes and used to meet mandatory obligations under the Kyoto Protocol. In Thailand, the implications for climate change mitigation projects in the mining industry, however, remain limited.

This paper explores the feasibility of CDM implementation and GHG emission reductions in the gold mining industry. The results found that comminution- the grinding and crushing of gold ore is the most significant source of GHG emissions and also the most energy intensive step in gold mining. Potentially, there are four technologies to reduce energy consumption and also $\mathrm{CO}_{2}$ emissions: i) HPGR, ii) VRM, iii) gravity pre-concentration, and iv) microwave heating technology. Meanwhile, the results of this study demonstrated that small-scale CDM project activities are very viable for the gold industry.

Recommendations for all relevant stakeholders and possible directions for further study were raised as follows: (a) Apart from the deployment of biogas and biomass projects, Thai authorities should consider the opportunities for expanding CDM projects into the mining industry; (b) Relevant provincial and central government agencies should provide adequate financial and human resources support for the implementation of climate change mitigation projects in the mining sector. Both actions and support would need to be Measurable, Reportable and Verifiable (MRV); (c) In the cost benefit analysis, it is important to carefully consider both GHG emission reduction potential and its abatement costs (i.e. estimation of $\mathrm{CO}_{2}$ abatement cost curve; ACC). For instance, [37] found that, by using a bottom-up ACC as the analytical tool, the cost effective annual $\mathrm{CO}_{2}$ abatement for the cement industry in Thailand during the 15-year scenario period (2010-2025) is approximately 3,095 ktonnes $\mathrm{CO}_{2} /$ year. Additionally, carbon trading information should also be accessible for all project developers; (d) Raising awareness of community partners and fostering cooperation across public and private sectors in responding to climate change, by 
reducing GHG emissions and enhancing its sinks and reservoirs, could be important; (e) To expand implementation of CDM projects in Thailand, it is necessary to build mechanisms and promote better coordination between the private and public sectors to facilitate private investment in GHG emissions reduction projects i.e. Emission Trading Scheme [41], [42]. Further research and development on the concept of carbon capture and sequestration (CCS) technologies [43] [47], Life Cycle Assessment (LCA) studies [48] and GHG mitigation associated with mining and mineral processing is urgently needed.

\section{ACKNOWLEDGEMENT}

The author would like to acknowledge support from the "Risk Assessment and Site Remediation (RAR) project", the Center of Excellence on Hazardous Substance Management and Environmental Research Institute of Chulalongkorn University, Thailand. Further to this point, this paper draws on material from a number of research projects done by the Department of Primary Industries and Mines, Ministry of Industry, Thailand and Faculty of Engineering, Chiang Mai University, Thailand. The author also wishes to express her special thanks to Mr. Phaichayon Charoenchaisri and Ms. Wannaporn Kwamsuk of the Department of Primary Industries and Mines for their support and assistance.

\section{REFERENCES}

[1] Stern N. Stern Review on the Economic of Climate Change. Cambridge, UK: Cambridge University Press, 2007.

[2] UNFCCC. Kyoto Protocol to the United Nations Framework Convention on Climate Change [Online]. Available: http://unfccc.int/cop5/resource/docs/cop3/107a01.pdf

[3] Kittipongvises S. Potential of clean development mechanism activities (CDM) activities for greenhouse gases reduction at a starch-processing factory in Thailand, Master's thesis. Asian Institute of Technology, Thailand, 2008.

[4] OECD. Policies to Reduce Greenhouse Gas Emissions in Industry - Successful Approaches and Lessons Learned: Workshop Report, OECD Paper 2004:4(2):1

[5] IPCC. Climate Change 2014: Mitigation of Climate Change. Contribution of Working Group III to the Fifth Assessment Report of the Intergovernmental Panel on Climate Change, Cambridge, United Kingdom and New York, USA: Cambridge University Press, 2014

[6] JGSEE, KMUTT. Thailand's Second National Communications to the UNFCCC: Greenhouse Gas Inventory [Online] Available: https://unfccc.int/files/national_reports/non-nnex_i_natcom/submitted_natcom/application/ pdf/snc_thailand.pdf

[7] IPCC. Fourth Assessment Report [Online]. Available: http://www.ipcc.ch/ipccreports/ar4-syr.htm

[8] TGO. Current Status of CDM in Thailand [Online]. Available: http://www.tgo.or.th/index.php?option=com_content\&view=category\&id=60\&Itemid=91

[9] UNFCCC. List of sectoral scopes [Online]. Available: http://cdm.unfccc.int/ DOE/scopelst.pdf

[10] Bank of Thailand. Thailand's economic condition in 2010 [Online]. Available: http://www.bot.or.th/English/EconomicConditions/Thai/report/AnnualReport Doc/AnnualReport 2010.pdf

[11] Department of Primary Industries and Mines, Ministry of Industry. Mineral Statistics of Thailand 2012-2013 (Fiscal year), 2014

[12] TGO. GHG emission by sector in $\mathrm{CO}_{2}$ equivalent (Million tons) and percent for 2000 [Online]. Available: http://www.tgo.or.th/english/index.php?option=com content $\& v i e w=a r t i c l e \& i d=45 \& I t e m i d=71$

[13] EPA's Greenhouse Gas Emission Reductions [Online]. Available: http://www.epa.gov/greeningepa/ghg/

[14] EPA. Quantifying Greenhouse Gas Emissions from Key Industrial Sectors in the United States: Working Draft, 2008

[15] Greenhouse Gas Division Environment Canada. Guidance Manual for Estimating Greenhouse Gas Emissions: Metal Mining [Online]. Available: http://publications.gc.ca/collections/Collection/En49-2-9-2E.pdf

[16] Mining Association of Canada, Inventorying, Measuring and Reporting on Climate Change Actions, Report, Pembina Institute and Stratos Inc, 2000

[17] GAIMAN. Gold Recovery Processes [Online]. Available: http://64.17.179.176/blog/gold-recovery-processes.html

[18] Department of Primary Industries and Mines, Ministry of Industry and Faculty of Engineering, Chiang Mai University, Thailand. An evaluation of CDM project development in the mining industry: Final report, 2010.

[19] TGO. Carbon Footprint for Organization: Emission factor [Online]. Available: http://thaicarbonlabel.tgo.or.th/ download/Emission_Factor_CFO.pdf

[20] TGO. Carbon Footprint of Products: Emission factor [Online]. Available: http://thaicarbonlabel.tgo.or.th/ download/Emission Factor CFP.pdf

[21] Norgate T., Haque N. Energy and greenhouse gas impacts of mining and mineral processing operations. Journal of Cleaner Production 2010:18:266-274. doi:10.1016/j.jclepro.2009.09.020 
[22] Norgate T., Haque N. Using life cycle assessment to evaluate some environmental impacts of gold production. Journal of Cleaner Production 2012:29-30:53-63. doi:10.1016/j.jclepro.2012.01.042

[23] Boyan R., Peter S. Preliminary GHG Emission Inventory, DPM Krumovgrad, Sofia, Bulgaria [Online]. Available: http://www.dundeeprecious.com/files/technical_reports/Preliminary_GHG_Inventory_EN_v001_y248z1.pdf

[24] Haque N., Norgate T. The greenhouse gas footprint of in-situ leaching of uranium, gold and copper in Australia. Journal of Cleaner Production 2014:84:382-390. doi:10.1016/j.jclepro.2013.09.033

[25] Yahaya N. R., Murad M., Morad N., Fizri F. F. A. Environmental impact of electricity consumption in crushing and grinding processes of traditional and urban gold mining by using life cycle assessment (LCA). Iranica Journal of Energy \& Environment 2012:3:66-73.

[26] UNFCCC. Report of the Conference of the Parties on its seventh session. Addendum part two: Action taken by the Conference of the Parties. Vol. II. Modalities and procedures for a clean development mechanism as defined in Article 12 of the Kyoto Protocol, Marrakech, 2001.

[27] Gary C. The Clean Development Mechanism as a Vehicle for Technology Transfer and Sustainable Development Myth or Reality? Law, Environment and Development Journal 2010:6(2):179.

[28] Chavalala B., Nhamo G. Clean and energy efficient technology as green economy transition mechanism in South African gold mining: case of Kusasalethu. Environmental Economics 2014:5:74-83.

[29] US Department of Energy. Industrial Technologies Program. Mining Industry Energy Bandwidth Study June 2007 [Online]. Available: http://www1.eere.energy.gov/manufacturing/resources/mining/pdfs/mining_bandwidth.pdf

[30] Taylor A. Gold technology developments and trends. ALTA 2010 Gold Conference, Perth, Western Australia, 2010

[31] Dunne R. C., Goulsbra A., Dunlop I. High pressure grinding rolls and the effect on liberation: Comparative Test Results. Randol Gold Forum 96, Olympic Valley, 1996

[32] Van der Meer F., Maphosa W. High pressure grinding moving ahead in copper, iron and gold processing. $6^{\text {th }}$ Southern African Base Metals Conference, Phalaborwa, South Africa, 2011:389-410.

[33] Cembureau, Best Available Techniques for the Cement Industry, Brussels: Cembureau, 1997.

[34] Institute for industrial productivity. Vertical Roller Mills for finish grinding [Online]. Available: http://ietd.iipnetwork.org/content/vertical-roller-mills-finish-grinding

[35] Harcus M. Golden age. Mining Magazine 2011:57-67

[36] Chadwick J. Golden horizons. International Mining 2011:68-76

[37] Hasanbeigi A., Menke C., Price L. The $\mathrm{CO}_{2}$ abatement cost curve for the Thailand cement industry. Journal of Cleaner Production 2010:18:1509-1518. doi:10.1016/j.jclepro.2010.06.005

[38] Hasanbeigi A., Price L., Lu H., Lan W. Analysis of energy-efficiency opportunities for the cement industry in Shandong Province, China: A case study of 16 cement plants. Energy 2010:35:3461-3473 doi:10.1016/j.energy.2010.04.046

[39] Worrell E., Galitsky C., Price L. Energy Efficiency Improvement Opportunities for the Cement Industry. Berkeley, CA: Lawrence Berkeley National Laboratory, 2008 [Online]. Available: http://ies.lbl.gov/node/402

[40] Šommet J. Sustainable Development in Estonian Mining. Environmental and Climate Technologies 2013:11:31-40. doi:10.2478/rtuect-2013-0005

[41] Pruse I. European Union Emissions Trading System with Regard to Climate Change Mitigation in Latvia. Environmental and Climate Technologies 2012:8:29-35. doi:10.2478/v10145-012-0005-y

[42] Laicane I., Rosa M., Dzene I. Application of $\mathrm{CO}_{2}$ Taxes for Combustion Installations in Latvia until 2020. Environmental and Climate Technologies 2012:6:44-48. doi:10.2478/v10145-011-0006-2

[43] Liang X., Wang Z., Zhou Z., Huang Z., Zhou J., Cen K. Up-to-date life cycle assessment and comparison study of clean coal power generation technologies in China. Journal of Cleaner Production 2013:39:24-31. doi:10.1016/i.jclepro.2012.08.003

[44] Korre A., Nie Z., Durucan S. Life cycle modelling of fossil fuel power generation with post-combustion $\mathrm{CO}_{2}$ capture. International Journal of Greenhouse Gas Control 2010:4:289-300. doi:10.1016/j.egypro.2009.02.177

[45] Nie Z., Korre A., Duracan S. Life cycle modelling and comparative assessment of the environmental impacts of oxyfuel and post-combustion $\mathrm{CO}_{2}$ capture, transport and injection processes. Energy Procedia 2011:.4:2510-2517. doi:10.1016/j.egypro.2011.02.147

[46] Odeh N. A., Cockerill T. T. Life cycle GHG assessment of fossil fuel power plants with carbon capture and storage. Energy Policy 2010:36:367-380. doi:10.1016/j.enpol.2007.09.026

[47] Banan Z., Maleki A. Carbon Capture \& Storage Deployment in Iran. Energy Procedia 2013:37:7492-7501. doi:10.1016/j.egypro.2013.06.693

[48] Heijungs R. Ecodesign - carbon footprint - life cycle assessment - life cycle sustainability analysis. A flexible framework for a continuum of tools. Environmental and Climate Technologies 2010:4:42-46. doi:10.2478/v10145$\underline{010-0016-5}$ 


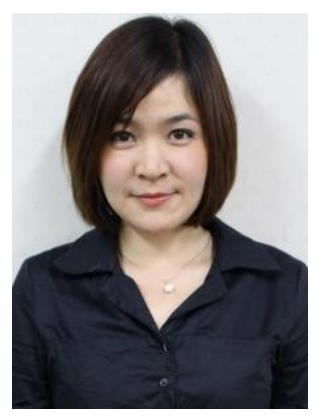

Dr. Suthirat Kittipongvises is currently a lecturer at Environmental Research Institute, Chulalongkorn University (ERIC), Thailand. She has a PhD in Sustainability Science from the Graduate Program in Sustainability Science, Global Leadership Initiative (GPSS-GLI), Graduate School of Frontier Sciences, the University of Tokyo, Japan in 2013. She also earned a Master of Science degree from the Environmental Engineering and Management from the School of Environment, Resources and Development, Asian Institute of Technology (AIT), Thailand in 2008. Her research focuses on the study of climate change mitigation, public perceptions and understanding of global climate change, the concept of sustainable development, environmental policy and planning, environmental concerns and worldviews. Further to this, she has attended and presented her research at various conferences including International Climate Change in Copenhagen, Denmark in 2009, International Conference of Climate Change and Global Warming (ICCCGW), the World Academy of Science, Engineering and Technology, Venice, Italy in 2011, International Conference on Sustainability Science (ICSS), Arizona, USA in 2012, International Conference on Ecology, Ecosystems and Climate Change, Athens, Greece in 2013, International Expert Dialogue on Applying Resilience Concept for Climate Change Study and Disaster Management in Thailand Context, Bangkok, Thailand in 2014, and International Conference on Environmental Science and Development, Amsterdam, Netherland in 2015. 